\title{
Comparison Of Simple Moving Average and Exponential Smoothing Methods To Predict Seaweed Prices
}

\author{
Harliyus Agustian ${ }^{* 1}$, Asih Pujiastuti ${ }^{2}$, Muhammad Varian Sayoga ${ }^{3}$ \\ $1,2,3$ \\ Program Studi Informatika, Sekolah Tinggi Teknologi Adisutjipto \\ E-mail : ${ }^{* 1}$ harliyus@stta.ac.id, $\underline{2}$ asihpuji@stta.ac.id, $\underline{\text { sayogavm@gmail.com }}$
}

\begin{abstract}
Seaweed is one of the main superior commodities in the City of Tarakan. The problem often faced in the field is that the increase in production is not proportional to the price of seaweed that fluctuates every month from year to year, making it difficult for collectors to determine the price of seaweed for sale. Price increases caused by various factors such as the drying process, long marketing chains, and increasing demand from domestic companies. In determining the price of seaweed in the future some approach is needed to predict or predict the price of seaweed in the following month. Forecasting (forecast) is an activity or business that knows the events that will occur at that time will use historical data. Prediction methods used in this study are Simple Moving Average and Exponential Smoothing, these two methods will be guided to find out the most appropriate method used in predicting. Based on the minimum error value calculated using the values of MAD, MSE, MFE, MAPE and CFE, it is found that the Simple moving average forecasting method is considered the best method that can be used to forecast seaweed prices.
\end{abstract}

Keywords - Seaweed, simple moving average, exponential smoothing

\section{INTRODUCTION}

Seaweed is very popular in the world of commerce. In the world of science, seaweed is known as Algae ${ }^{[1]}$. Seaweed cultivation or Uucheuma Cottonii in the City of Tarakan waters has been going on since 2011. At first only as a side effort when it stopped fishing. However, it turns out that this business is growing rapidly so that there is a change in the paradigm of the seaweed farming community which was originally a side business has now become a major business. Seaweed cultivation has no legal rules to regulate aquaculture activities ${ }^{[2]}$. Seaweed productivity in every region in Indonesia is not the same, this is caused by seaweed cultivation, how to cultivate seaweed, seaweed demand, season, and others. In 2013, seaweed production reached 5,000 tons of dried seaweed. In 2014, the productivity of Tarakan City's seaweed increased to 8,000 tons and continued to increase ${ }^{[3]}$.

Most collectors sell the price of dried seaweed because the price is more expensive. To get dried seaweed, farmers do the drying process to eliminate the water content. Factors that influence the rise and fall of seaweed prices include seaweed quality standards that must be appropriate because the seaweed quality standard must be $25 \%$. The marketing chain also affects the ups and downs of prices because this long marketing chain automatically makes collectors push the price of seaweed. In addition, there is also a lack of demand from domestic companies, so traders collect the price of seaweed. The increase in production is not proportional to the price of seaweed that fluctuates every month from year to year. Fluctuating prices make it difficult for collectors to determine the price of seaweed to be sold. The influencing factors are the long marketing chain, the quality of seaweed, and the weather when drying seaweed.

The increase in seaweed prices that continue to rise and fall every month, can show patterns of rising and falling seaweed prices so we need a data processing that can search for these patterns to find out or get the appropriate price of seaweed. The data patterns obtained can help collectors to predict future seaweed prices based on previous seaweed price data, to find out the data patterns formed, a data mining approach is needed to predict seaweed prices. Data mining approaches are widely applied, such as the implementation of data mining to predict sales in minimarkets using the time series method ${ }^{[4]}$. 
Data mining approach with the APRIORI method in the transaction of sale of goods ${ }^{[5]}$. Two level clustering approach for the analysis of academic questionnaire results for data mining problems ${ }^{[6]}$. Data mining approach to research on decision support systems prediction of the number of Trans Jogja passengers ${ }^{[7]}$.

Prediction or forecasting is also used in solving several cases in data mining such as the application of seaweed prediction can be found in time series forecasting research using S-Curve and Quadratic Trend Model, in the study of the authors aims to make time series forecasting of dry seaweed production on the island of Nusa Penida by combining two methods, namely S-Curve and Quadratic Trend Model so that it can know the level of productivity of grass production dry sea produced ${ }^{[8]}$, palm oil selling prediction based on fruit quality with a backpropagation approach on artificial neural networks ${ }^{[9]}$, ARIMA time series modeling in predicting chili prices to anticipate fluctuating market demand ${ }^{[10]}$. In predicting many algorithms that can be used depending on the type of data and patterns obtained, to get a good method requires a comparison of two or more methods to get an appropriate prediction price, such as prediction of the gold price with Linear Regression, Backpropagation and Fuzzy Mamdani approaches, so that the algorithm the best in predicting the price of gold is Backpropagation, followed by linear regression ${ }^{[11]}$, also the estimation of the forecast model of rice prices at the wholesale level to predict rice prices at the trader level ${ }^{[12]}$.

Based on this background, we need a method approach that can help in predicting seaweed prices, by comparing several methods, namely Simple Moving Average and Exponential Smoothing in order to obtain the appropriate method for predicting seaweed prices in the next period. The results of these forecasts can at least help traders to predict future prices and can provide information to formulate business strategies and also anticipate fluctuating market demand. In this method, data from previous seaweed prices will be used. In this method the price data used to predict is the price of seaweed in Tarakan City.

\section{RESEARCH METHODS}

\subsection{Data Mining}

Data mining is a process of finding useful new correlations, patterns that are obtained by mining a large number of data repositories ${ }^{[13]}$. Data mining, there are several techniques, one of them is Forecasting is an activity or effort to find out the events that will occur in the future using judgment, experiences or historical data ${ }^{[14]}$. Some methods that can be used in predicting are Simple Moving Average and Exponential Smoothing.

\subsection{Simple Moving Average}

This method uses a data set with a fixed amount of data, according to the period of movement and then the average value of the data set is used to predict the value of the next period ${ }^{[15]}$. How to calculate the moving average is as follows:

Information:

$$
\begin{aligned}
& \mathrm{S}^{\prime}=1 / \mathrm{N}\left(\mathrm{X}_{\mathrm{t}}+\mathrm{X}_{\mathrm{t}-1}+\mathrm{X}_{\mathrm{t}-2}+\ldots .+\mathrm{X}_{\mathrm{t}-\mathrm{N}-1}\right) \\
& \mathrm{S}^{\prime}{ }_{\mathrm{t}}=1 / \mathrm{N}\left(\mathrm{S}_{\mathrm{t}}{ }_{\mathrm{t}}+\mathrm{S}_{\mathrm{t}-1}+\mathrm{S}_{\mathrm{t}-2}+\ldots .+\mathrm{S}_{\mathrm{t}-\mathrm{N}-1}\right)
\end{aligned}
$$

$\mathrm{S}_{\mathrm{t}}=$ Simple Moving Average.

$\mathrm{S},{ }_{\mathrm{t}}=$ Double Moving Average.

$\mathrm{t}=$ Period.

$\mathrm{N}=$ Amount of data divisor.

$\mathrm{S}_{\mathrm{t}}=$ Simple Moving Average.

$\mathrm{X}_{\mathrm{t}}=$ Field data.

$$
\mathrm{F}_{\mathrm{t}+\mathrm{m}}=\mathrm{S}_{\mathrm{t}}{ }_{\mathrm{t}}(2+2 / \mathrm{N}-1)-\mathrm{S}^{\prime}{ }_{\mathrm{t}}(1+2 / \mathrm{N}-1)
$$

Information :

$\mathrm{F}_{\mathrm{t}+\mathrm{m}}=$ Forecasting the next period.

$\mathrm{S}{ }{ }_{\mathrm{t}}=$ Double Moving Average.

$\mathrm{N}=$ Amount of data divisor.

$\mathrm{m}=$ Period.

$\mathrm{S}_{\mathrm{t}}=$ Simple Moving Average. 


\subsection{Exponential Smoothing}

The single exponential smoothing method is adaptive with $\mathrm{k}$ values that can change in a controlled manner, especially when there is a change in the data pattern. This means that the $\mathrm{k}$ value will change or be adaptive automatically if there is a change in the data pattern ${ }^{[14]}$. Exponential smoothing is very suitable to be used to predict things that fluctuate randomly or irregularly ${ }^{[15]}$ :

$$
S^{\prime}{ }_{t+1}=k\left(X_{t}\right)+(1-k) S^{\prime}{ }_{t}
$$

Information:

$\mathrm{S}_{\mathrm{t}+1}^{\prime}=$ Exponential smoothing.

$\mathrm{X}_{\mathrm{t}}=$ Field data.

$\mathrm{t}=$ Period.

$\mathrm{k} \quad=$ Flutuative estimate value.

$\mathrm{S}_{\mathrm{t}}=$ Forecast results.

$$
\mathrm{S}{ }^{\prime}{ }_{\mathrm{t}+1}=\mathrm{k}\left(\mathrm{S}_{\mathrm{t}}\right)+(1-\mathrm{k}) \mathrm{S}{ }^{\prime}{ }_{\mathrm{t}}
$$

Information :

$\mathrm{S},{ }_{\mathrm{t}+1}=$ Double exponential smoothing,

$\mathrm{S}_{\mathrm{t}}{ }_{\mathrm{S}} \quad=$ Single Exponential Smoothing forecasting results

$\mathrm{k}=$ Flutuative estimate value.

$\mathrm{S}{ }^{\prime}{ }_{\mathrm{t}}=$ Double Exponential Smoothing forecasting results

$$
\mathrm{t}=\text { Period. }
$$

$$
\mathrm{F}_{\mathrm{t}+1}=\mathrm{S}_{\mathrm{t}}\left(2+\frac{k}{1-k}\right)-\mathrm{S}^{\prime}{ }_{\mathrm{t}}\left(1+\frac{k}{1-k}\right)
$$

Faktor pembobotan untuk $\mathrm{S}_{\mathrm{t}}$ adalah $2+(\mathrm{k} / 1-\mathrm{k})(\mathrm{m})$ dan untuk $\mathrm{S}{ }^{\prime}{ }_{\mathrm{t}}$ adalah $1+(\mathrm{k} / 1-$ $\mathrm{k})(\mathrm{m})$.

Information :

$\mathrm{F}_{\mathrm{t}+1}=$ Forecast results for the next period

$\mathrm{t}=$ Periode

$\mathrm{S}_{\mathrm{t}}{ }=$ Single Exponential Smoothing forecasting results,

$\mathrm{S},{ }_{\mathrm{t}}=$ Double Exponential Smoothing forecasting results

$\mathrm{k}=$ Nilai perkiraan flutuatif

\subsection{Measurement of Forecasting Accuracy Results}

Measurement of forecasting accuracy results is done to get better results between the two methods and testing is done by calculating the value of Mean Absolute Deviation (MAD), Mean Forecast Error (MFE), Mean Square Error (MSE) and Mean Absolute Presentation Error (MAPE).

\subsubsection{Mean Absolute Deviation}

Mean Absolute Deviation (MAD) is the average absolute error over a certain period regardless of whether the forecasting result is greater or smaller than the reality. MAD is the first measure of overall forecasting error for a model ${ }^{[16]}$. This value is calculated by taking the absolute value of each forecast error divided by the number of data periods ${ }^{[17]}{ }^{[18]}$. MAD is systematically formulated as follows:

$$
M A D=\frac{\sum \text { |actual }- \text { forecasting } \mid}{\mathrm{n}}
$$

Information :

$\mathrm{n}=$ The number of months used

\subsubsection{Mean Square Error}

Mean Square Error (MSE) is calculated by summing the square of all forecasting errors in each period and dividing by the number of forecasting periods [18]. MSE is systematically formulated as follows: 
Information :

$$
M S E=\frac{\left.\sum \text { (actual }- \text { forecasting }\right)^{2}}{\mathrm{n}}
$$

$\mathrm{n}=$ The number of months used

\subsubsection{Mean Forecast Error}

Mean Forecast Error MFE is the average error by measuring the ratio of the number of errors divided by the number of data forecasting periods. MFE is very effective for knowing whether a forecast result over a certain period is too high or too low. MFE is calculated by adding up all forecasting errors during forecasting periods and dividing them by the number of forecasting periods ${ }^{[18]}$. The MFE is systematically stated as follows:

Information :

$$
M F E=\frac{\sum \text { actual }- \text { forecasting }}{\mathrm{n}}
$$

$\mathrm{n}=$ The number of months used

\subsubsection{Mean Absolute Percentage Error}

Mean Absolute Percentage Error (MAPE) is a measure of relative error. MAPE is usually more meaningful than MAD because MAPE states the percentage of error forecasting results from actual requests during a certain period which will give information the percentage of error is too high or too low, in other words MAPE is the average absolute error during a certain period which is then multiplied by $100 \%$ so get a percentage result ${ }^{[18]}$. MAPE is systematically formulated as follows:

$$
\text { MAPE }=\frac{\sum\left|\frac{\text { actual-forecasting }}{\text { actual }} \times 100 \%\right|}{\mathrm{n}}
$$

Information :

$\mathrm{n}=$ The number of months used

\subsubsection{Cumulative Forecast Error (CFE)}

Cumulative Forecast Error is a forecast error $=$ request - forecast. Systematically can be written as follows:

$$
C F E=\sum A t-F t
$$

Information :

At $=$ Actual

$\mathrm{Ft}=$ Forecasting

CFE has advantages, namely the measure of forecasting error which is used by adding forecasting errors and the drawback is that the accuracy of forecasting results is very small because it only uses the number of forecast errors as a measure of error.

\section{RESULTS AND DISCUSSION}

The results of data processing seaweed prices in July-December 2018 to predict seaweed prices in January-March 2019, conducted trials as much as 3 times a trial to get prediction results simple moving average and double moving average with for the next 3 months as shown in Table 1 , where $X t$ is the current price data for seaweed, $S^{\prime} t$ is the result of the calculation of the Simple Moving Average, $S^{\prime \prime} t$ is the result of the calculation of the Double Moving Average and $F t-1$ is the prediction result for the next 3 months. 
Table 1. Experimentation of the simple moving average method

\begin{tabular}{|c|c|c|c|c|c|c|}
\hline No & Trial & Month & Price $(\mathrm{Xt})$ & $S^{\prime} t$ & $S$ '”t & Prediction (Ft-1) \\
\hline 1. & Trial 1 & January 2018 & 9.500 & - & - & - \\
\hline 2. & Trial 1 & February 2018 & 12.000 & - & - & - \\
\hline 3. & Trial 1 & March 2018 & 12.500 & 11.333 & - & \\
\hline 4. & Trial 1 & April 2018 & 12.950 & 12.483 & - & 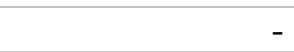 \\
\hline 5. & Trial 1 & May 2018 & 13.000 & 12.817 & 12.211 & \\
\hline 6. & Trial 1 & June 2018 & 13.500 & 13.150 & 12.817 & 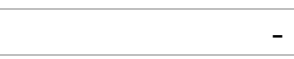 \\
\hline 7. & Trial 1 & July 2018 & 13.500 & - & - & 13.817 \\
\hline 8. & Trial 1 & August 2018 & 14.000 & - & - & 14.150 \\
\hline 9. & Trial 1 & September 2018 & 14.825 & - & - & 14.483 \\
\hline 10. & Trial 2 & April 2018 & 12.950 & - & - & 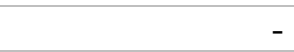 \\
\hline 11. & Trial 2 & May 2018 & 13.000 & - & - & - \\
\hline 12. & Trial 2 & June 2018 & 13.500 & 13.150 & - & - \\
\hline 13. & Trial 2 & July 2018 & 13.500 & 13.333 & - & - \\
\hline 14. & Trial 2 & August 2018 & 14.000 & 13.667 & 13.383 & \\
\hline 15. & Trial 2 & September 2018 & 14.825 & 14.108 & 13.703 & - \\
\hline 16. & Trial 2 & October 2018 & 15.000 & - & - & 14.919 \\
\hline 17. & Trial 2 & November 2018 & 16.500 & - & - & 15.325 \\
\hline 18. & Trial 2 & December 2018 & 16.900 & - & - & 15.731 \\
\hline 19. & Trial 3 & July 2018 & 13.500 & - & - & 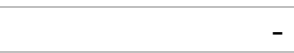 \\
\hline 20. & Trial 3 & August 2018 & 14.000 & - & - & - \\
\hline 21. & Trial 3 & September 2018 & 14.825 & 14.108 & - & - \\
\hline 22. & Trial 3 & October 2018 & 15.000 & 14.608 & - & \\
\hline 23. & Trial 3 & November 2018 & 16.500 & 15.442 & 14.719 & \\
\hline 24. & Trial 3 & December 2018 & 16.900 & 16.133 & 15.394 & \\
\hline 25. & Trial 3 & January 2019 & 17.350 & - & - & 17.611 \\
\hline 26. & Trial 3 & February 2019 & 17.850 & - & - & 18.350 \\
\hline 27. & Trial 3 & March 2019 & 18.000 & - & - & 19.089 \\
\hline
\end{tabular}

The first trial calculation calculates the value of simple moving average and double moving average using the previous month's data, namely January to June 2018 to predict seaweed prices for the next 3 months in July, August, September 2018 with the number $N=3$, so the results of manual calculations Simple Moving Average for forecasting seaweed prices in July at Rp. 13,817, for August, namely Rp. 14,150, while for September Rp. 14,483 in 2018.

The second trial calculation uses April to September 2018 to predict seaweed prices in October, November, December 2018 with $\mathrm{N}=3$, so the results of the calculation of the Simple Moving Average manual for forecasting seaweed prices in October are Rp. 14,919, for November that is Rp. 15,325, while for December Rp. 15,731 in 2018.

The third trial calculation uses July to December 2018 to predict seaweed prices in January, February, March 2019 with N = 3, so the Simple Moving Average manual calculation results for forecasting January seaweed prices are Rp. 17,611, for February, namely Rp. 18,350, while for March Rp. 19,089 in 2019.

The patterns generated by the Simple Moving Average method based on the data in Table 1 can be seen on the graph from July 2018 to March 2019 as shown in Figure 1. 


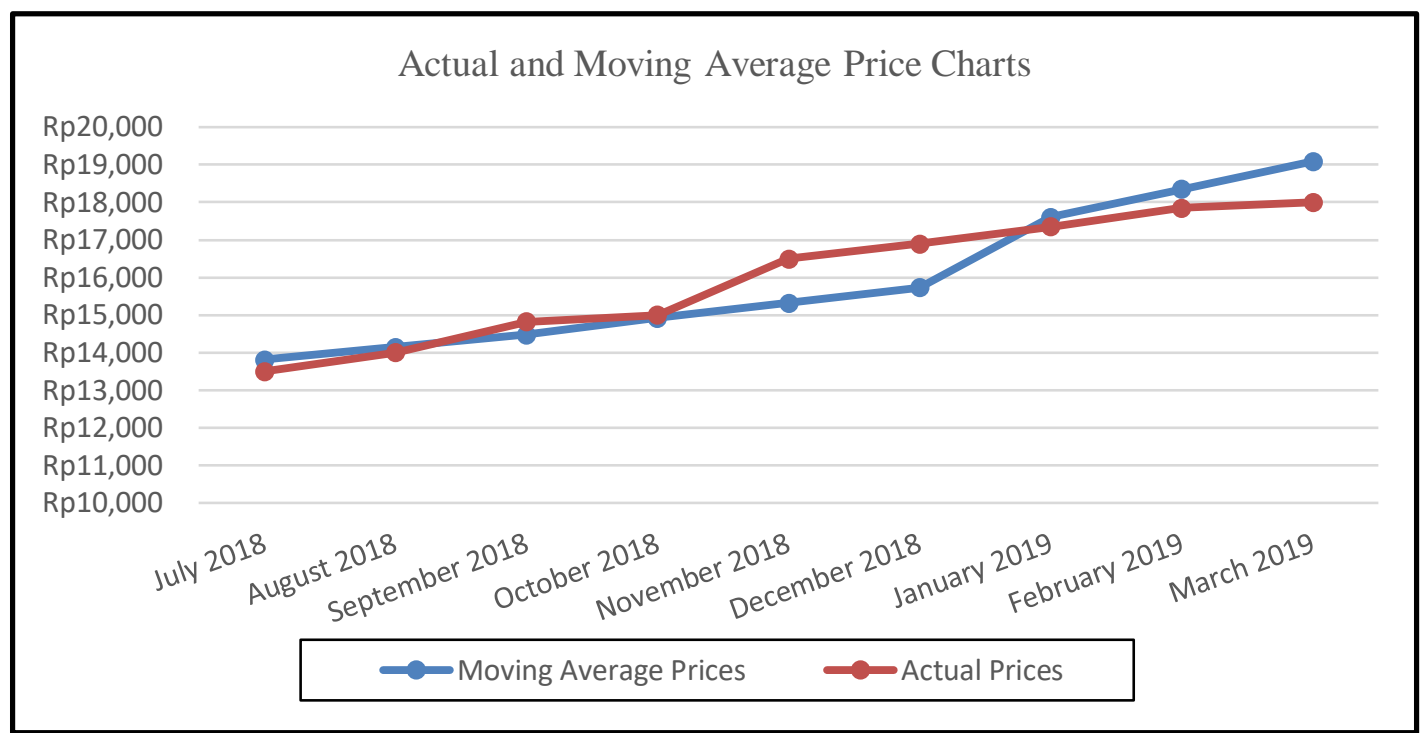

Figure 1. Comparison graph of actual and moving average prices

Based on the data in Table 1 and the graph in Figure 1, shows that the predicted price using the Moving Average method follows the pattern of the actual data graph.

The results of the experiment using Exponential Smoothing contained a trial column in the application, year seaweed price, month seaweed price, original price, Exponential Smoothing method, Double Exponential Smoothing method, and predictions for the next three months. There are three trials using fifteen data as shown in Table 2.

Table 2. Experiments of the exponential smooth method

\begin{tabular}{|c|l|l|r|r|r|r|}
\hline No & Trial & \multicolumn{1}{|c|}{ Month } & $\begin{array}{c}\text { Price } \\
(\mathbf{X t})\end{array}$ & \multicolumn{1}{|c|}{$\mathbf{S}^{\prime} \mathbf{t + 1}$} & \multicolumn{1}{|c|}{$\mathbf{S}{ }^{\prime \mathbf{t + 1}}$} & $\begin{array}{r}\text { Prediction } \\
\text { (Ft-1) }\end{array}$ \\
\hline 1. & Trial 1 & January 2018 & 9.500 & 9500 & 9500 & - \\
\hline 2. & Trial 1 & Februay 2018 & 12.000 & 10000 & 9600 & - \\
\hline 3. & Trial 1 & March 2018 & 12.500 & 10500 & 9780 & - \\
\hline 4. & Trial 1 & April 2018 & 12.950 & 10990 & 10022 & - \\
\hline 5. & Trial 1 & May 2018 & 13.000 & 11392 & 10296 & - \\
\hline 6. & Trial 1 & June 2018 & 13.500 & 11814 & 10600 & - \\
\hline 7. & Trial 1 & July 2018 & 13.500 & - & - & 13331 \\
\hline 8. & Trial 1 & August 2018 & 14.000 & - & - & 13635 \\
\hline 9. & Trial 1 & September 2018 & 14.825 & - & - & 13938 \\
\hline 10. & Trial 2 & April 2018 & 12.950 & 12950 & 12950 & - \\
\hline 11. & Trial 2 & May 2018 & 13.000 & 12960 & 12952 & - \\
\hline 12. & Trial 2 & June 2018 & 13.500 & 13068 & 12975 & - \\
\hline 13. & Trial 2 & July 2018 & 13.500 & 13154 & 13011 & - \\
\hline 14. & Trial 2 & August 2018 & 14.000 & 13324 & 13074 & - \\
\hline 15. & Trial 2 & September 2018 & 14.825 & 13624 & 13184 & - \\
\hline 16. & Trial 2 & October 2018 & 15.000 & - & - & 14174 \\
\hline 17. & Trial 2 & November 2018 & 16.500 & - & - & 14284 \\
\hline 18. & Trial 2 & December 2018 & 16.900 & - & - & 14394 \\
\hline 19. & Trial 3 & July 2018 & 13.500 & 13500 & 13500 & - \\
\hline 20. & Trial 3 & August 2018 & 14.000 & 13600 & 13520 & - \\
\hline 21. & Trial 3 & September 2018 & 14.825 & 13845 & 13585 & - \\
\hline 22. & Trial 3 & October 2018 & 15.000 & 14076 & 13683 & - \\
\hline 23. & Trial 3 & November 2018 & 16.500 & 14561 & 13859 & - \\
\hline 24. & Trial 3 & December 2018 & 16.900 & 15029 & 14093 & - \\
\hline 25. & Trial 3 & January 2019 & 17.350 & - & - & 16199 \\
\hline 26. & Trial 3 & Febuari 2019 & 17.850 & - & - & 16433 \\
\hline 27. & Trial 3 & March 2019 & 18.000 & - & - & 16667 \\
\hline & & & & & \\
\hline
\end{tabular}


Exponential smoothing Table 2 description:

$\mathrm{S}$ ' $+1=$ Exponential Smoothing

$\mathrm{S}^{\prime} 1+1=$ Double Exponential Smoothing

In the calculation for the first trial using data 6 months earlier from January - June 2018 to get a prediction of seaweed prices the next 3 months in July-September 2018, the first step is to determine $\mathrm{k}=0.2$ as an estimated fluctuating value. Fluctuating values can be determined free which is important between 0-1. The Double Exponential Smoothing method uses the same fluctuating value as the Exponential Smoothing method, which is $\mathrm{k}=0.2$, so the results of the Exponential Smoothing calculation for forecasting seaweed prices in July are Rp. 13,331, for the month of August Rp. 13,635, while for September Rp. 13,938 in 2018.

In the second trial calculation the estimated fluctuating value for exponential smoothing and double exponential smoothing is $\mathrm{k}=0.2$ with data from April - September 2018 to predict the next 3 months namely October-December 2018, so the results of the calculation of Exponential Smoothing for forecasting seaweed prices in October Rp. 14,174, for November Rp. 14,284, while for December Rp. 14,394 in 2018.

In the third trial calculation the estimated fluctuating values for exponential smoothing and double exponential smoothing are $\mathrm{k}=0.2$ with data from July - December 2018 to predict the next 3 months namely January - March 2019, so the results of the Exponential Smoothing calculation for forecasting seaweed prices in January Rp. 16,199, for February Rp. 16,433, while for March Rp. 16,667 in 2019.

The patterns generated by the Exponential Smooth method based on the data in Table 2 can be seen in the graph from July 2018 to March 2019 in Figure 2.

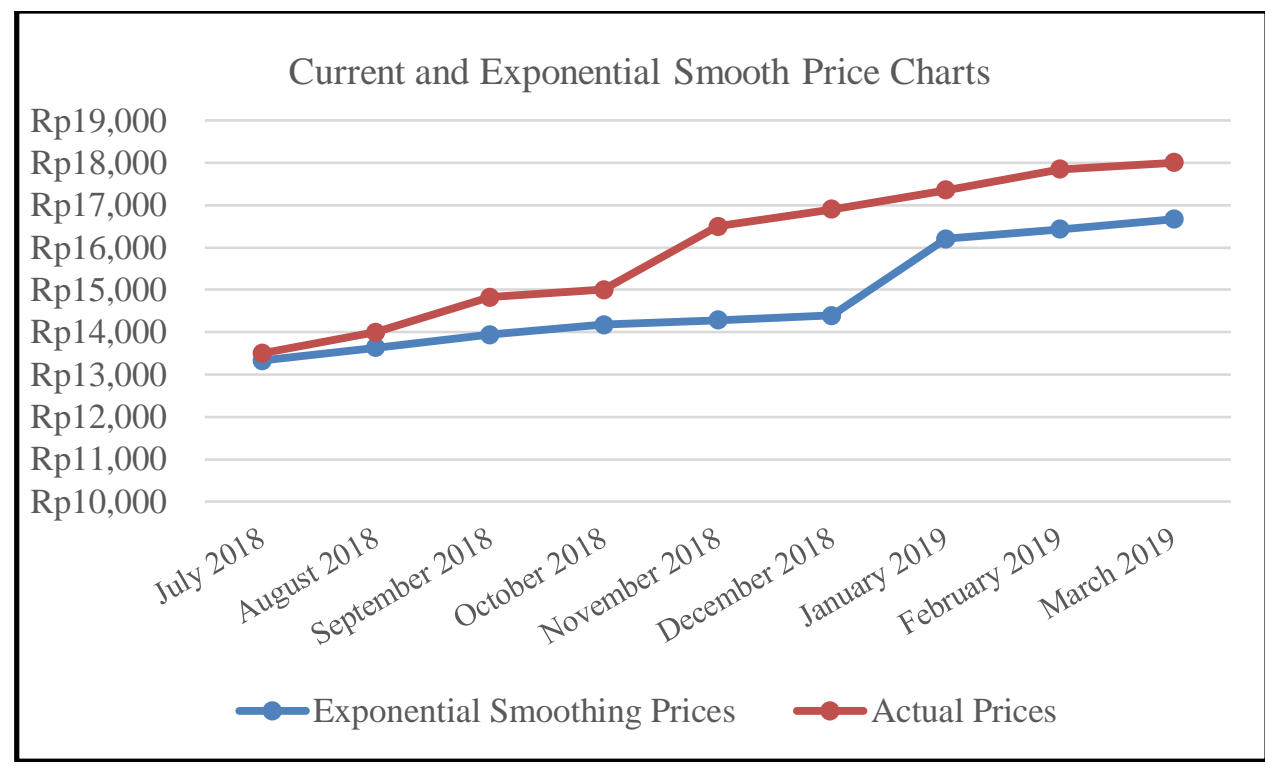

Figure 2. Comparison graph of actual and exponential smooth prices

Based on the data in the graph in Figure 2, shows that the predicted price in January 16,199, February 16,433, while March 16,667 for 2019, the pattern of data generated using the Exponential Smooth method follows the pattern of the actual data graph, on Exponential Smooth the difference between the predicted price with the actual price is quite far. The price difference between the method and the actual price as shown in Figure 3. 


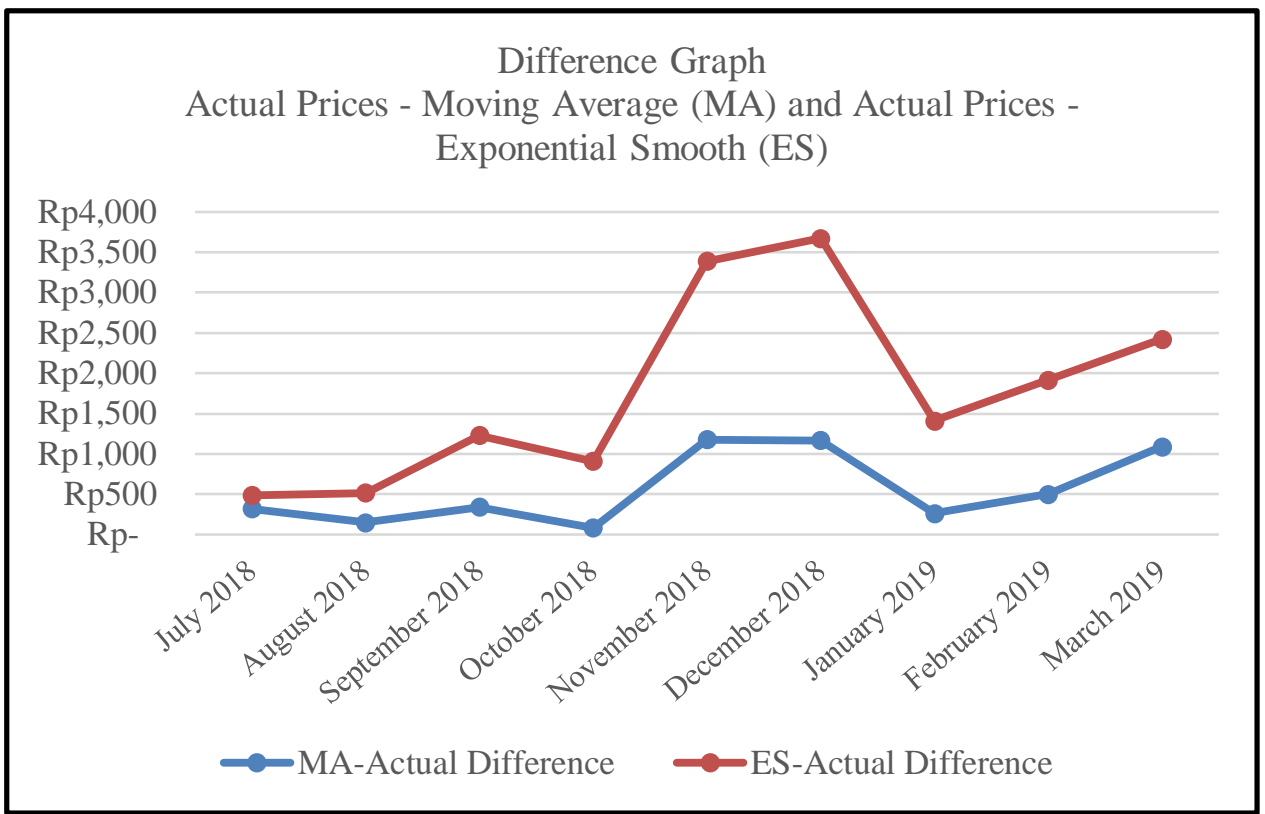

Figure 3. Graph of the difference between moving average and exponential smooth prices of actual prices

Based on the results from Figure 3 shows that the difference obtained between the two methods has the same pattern, the Exponential Smooth price difference is higher than the Moving Average.

In forecasting, there is a mismatch between the actual data and the forecast results. To detect the accuracy of the results of the forecast value compared to observations (actual data) for both methods of forecasting seaweed price data with Moving Average and Exponential Smoothing, it is necessary to determine the values of MAD, MSE, MFE, CFE and MAPE. The following is a comparison table between the measurement accuracy of MAD, MSE, MFE, MAPE and CFE forecasting for the two forecasting methods as in Table 3.

Table 3. Error calculation data on seaweed prices

\begin{tabular}{|c|c|c|c|}
\hline \multirow[b]{2}{*}{ Month } & \multirow{2}{*}{$\begin{array}{l}\text { Actual } \\
\text { Prices }\end{array}$} & \multicolumn{2}{|c|}{ Forecasting } \\
\hline & & $\begin{array}{l}\text { Moving } \\
\text { Average }\end{array}$ & $\begin{array}{l}\text { Exponential } \\
\text { Smoothing }\end{array}$ \\
\hline July 2018 & $\operatorname{Rp} 13,500$ & $\mathrm{Rp} \quad 13,817$ & $\mathrm{Rp} \quad 13,331$ \\
\hline August 2018 & Rp 14,000 & $\mathrm{Rp} \quad 14,150$ & $\mathrm{Rp} \quad 13,635$ \\
\hline September 2018 & $\operatorname{Rp} 14,825$ & $\mathrm{Rp} \quad 14,483$ & $\mathrm{Rp} \quad 13,938$ \\
\hline October 2018 & Rp 15,000 & $\mathrm{Rp} \quad 14,919$ & $\mathrm{Rp} \quad 14,174$ \\
\hline November 2018 & Rp 16,500 & $\mathrm{Rp} \quad 15,325$ & $\mathrm{Rp} \quad 14,284$ \\
\hline December 2018 & $\operatorname{Rp} 16,900$ & $\mathrm{Rp} \quad 15,731$ & $\mathrm{Rp} \quad 14,394$ \\
\hline January 2019 & Rp 17,350 & $\mathrm{Rp} \quad 17,611$ & $\mathrm{Rp} \quad 16,199$ \\
\hline February 2019 & $\operatorname{Rp} 17,850$ & $\mathrm{Rp} \quad 18,350$ & $\mathrm{Rp} \quad 16,433$ \\
\hline March 2019 & $\mathrm{Rp} 18,000$ & $\mathrm{Rp} \quad 19,089$ & $\mathrm{Rp} \quad 16,667$ \\
\hline MAD & & 564.889 & 1207.778 \\
\hline MSE & & 499749.111 & 1992344.667 \\
\hline MFE & & 50.000 & 1207.778 \\
\hline MAPE & & 3.407 & 7.287 \\
\hline CFE & & 450 & 10870 \\
\hline
\end{tabular}

Comparison of MAD, MSE, MFE, MAPE and CFE data in Table 3 shows the moving average forecasting method produces minimum MAD, MSE, MFE, MAPE and CFE values so that the forecasting method is considered the best method that can be used for forecasting. 


\section{CONCLUSION}

The MAD, MSE, MFE, MAPE and CFE results for the Moving Average method get the smallest error rate of MAD 568.9, MSE 99749.1, MFE 50, CFE 450 and MAPE 3.407 compared to the Exponential Smooth method, so that the method Simple Moving Average is better than the Exponential Smooth method in predicting seaweed prices.

\section{SUGGESTED}

Suggestions that can be given in order to improve and develop are:

1. Increase the price of seaweed studied.

2. in the future we can add the value of the error size used with Tracking Signals.

\section{REFERENCES}

[1] Indriani, H. dan E. Sumiarsih. 1997. Budidaya, Pengolahan, dan Pemasaran Rumput Laut. Edisi Pertama. Cetakan Lima. PT. Penebar Swadaya. Jakarta.

[2] Avianti, E., N. Hendiarti, dan T. Handayani. (2015). Kesesuaian Lahan Budidaya Rumput Laut Eucheuma Cottonii di Perairan Tarakan Dengan Faktor Pembatas Variabilitis Enso dan Musim. 11 (1): 13-24. Jakarta.

[3] Imam, M. (2016). Jurnal Ilmu Pemerintahan .Studi Tentang Pemberdayaan Masyarakat Petani Rumput Laut di Kelurahan Pantai Amal Kecamatan Tarakan Timur Kota Tarakan. Samarinda 4(1): 64-77.

[4] Widyatmoko, H., A. S. Honggowibowo., dan N. C. D. Retnowati. (2012). Implementasi Data Mining Untuk Meramalkan Penjualan di Minimarket Idola Jl. Pati Tambakromo Km 2 Desa Karangmulyo RT 08 RW 1 Dengan Metode Time Series. Compiler, 1(2).

[5] Sihombing, E. S., A. S. Honggowibowo., D. Nugraheny. (2012). implementasi data mining menggunakan metode APRIORI pada transaksi penjualan barang (studi kasus di chorus minimarket). Compiler, 1(1).

[6] Agustian, H. (2017). Two Level Clustering Untuk Analisis Kuesioner Akademik di Sekolah Tinggi Teknologi Adisutjipto Yogyakarta.

[7] Prasetiyo, D. (2013). Sistem Pendukung Keputusan Prediksi Jumlah Penumpang Untuk Evaluasi Kapasitas Halte Bus Trans Jogja Dengan Metode Exponential Smoothing Dan Least Square. Compiler, 2(1).

[8] Kadek, N. S. (2015). Peramalan Deret Waktu Menggunakan S-Curve dan Quadratic Trend Model. Konferensi Nasional Sistem dan Informatika. 9-10 October. 592-597.

[9] Andriyani, S., dan N. Sitohang. 2018. Implementasi Metode Backpropagation Untuk Prediksi Harga Jual Kelapa Sawit Berdasarkan Kualitas Buah. Jurnal Teknologi dan Informasi 4(2): 155-164.

[10] Hadiansyah, F.N. 2017. Prediksi Harga Cabai dengan Pemodelan Time Series ARIMA. Jurnal .2 (1): 71-78.

[11] Nafi'iyah, N. 2016. Perbandingan Regresi Linear, Backpropagation, dan Fuzzy Mamdani Dalam Memprediksi Harga Emas. Seminar National Inovasi dan Aplikasi Teknologi di Industri. Universitas Islam lamongan. B 291-B 296.

[12] Sukiyono, K., dan Rosdiana. 2018. Pendugaan Model Peramalan Harga Beras Pada Tingkat Grosir. Jurnal AGRISEP 17 (1): 23-30.

[13] Fatmawati, K., dan A. P. Windarto. 2018. Data Mining: Penerapan Rapidminer Dengan KMeans Cluster Pada Daerah Terjangkit Demam Berdarah Dengue (DBD) Berdasarkan Provinsi. Jurnal of Computer Engginering System and Science, 3(2).

[14] Awat, N., J. (1990). Metode Peramalan Kuantitatif edisi pertama. cetakan pertama. Yogyakarta. Liberty Yogyakarta.

[15] Robbiarni, D. (2004). Penjadwalan Produksi Dengan Metode Program Dinamis Untuk Meminimalkan Biaya Produksi (Skripsi, Universitas Islam Indonesia).

[16] Prasetio, E., dan M. Irawaty. 2014. Sistem Pendukung Keputusan Untuk Memprediksi Jumlah Pakaian Dengan Menggunakan Metode Weight Moving Average dan Exponential Smoothing. Compiler, 3(2). 
[17] Sanny L., dan H, Sarjono. (2013). Peramalan Jumlah Siswa/I Sekolah Menengah Atas Swasta Menggunakan Enam Metode Forecasting. Jakarta. 10(2).

[18] Saputro, A., \& Purwanggono, B. (2016). Peramalan Perencanaan Produksi Semen dengan Metode Exponential Smoothing pada PT. Semen Indonesia. Industrial Engineering Online Journal, 5(4). 